\title{
Effect of starch level in supplement with or without oil source on diet and apparent digestibility, rumen fermentation and microbial population of Nellore steers grazing tropical grass
}

\author{
Antonio Jose Neto ${ }^{a}$, Juliana D. Messana ${ }^{a}, *$ Yury T. Granja-Salcedo ${ }^{a}$, Pablo S. Castagnino ${ }^{a}$, \\ Giovani Fiorentini ${ }^{\mathrm{a}}$, Ricardo A. Reis ${ }^{\mathrm{a}, \mathrm{b}}$, Telma T. Berchielli ${ }^{\mathrm{a}, \mathrm{b}}$ \\ a Department of Animal Science, São Paulo State University (Unesp), School of Agricultural and Veterinarian Sciences, Jaboticabal, São Paulo CEP 14884-900, Brazil \\ ${ }^{\mathrm{b}}$ INCT/CA - UFV - Department of Animal Science, Viçosa, Minas Gerais CEP 36570-000, Brazil
}

\section{A R T I C L E I N F O}

\section{Keywords:}

Bacteria

Digestion

Lipid

Microbial protein

Protozoa

Soybean hull

\begin{abstract}
A B S T R A C T
In this study, we evaluated the effects of starch level in supplement, with/without whole soybean (oil source), on diet intake and apparent digestibility, rumen microbial population, and fermentation parameters in Nellore steers grazing Brachiaria brizantha cultivar Xaraés during the finishing phase. Eight ruminal cannulated Nellore steers $(514 \mathrm{~kg} \pm 30$ ) were used in a replicate $4 \times 4$ Latin square with a $2 \times 2$ factorial arrangement of treatments. The diets used had different levels of supplemented starch [corn (high) or soybean hulls (SH: low)] with/ without a source of oil (soybean grain). There were no interactions between starch level and oil in supplements on the intake of DM (\% of body weight, $P=0.602 ; \mathrm{kg} / \mathrm{d}, P=0.703)$, forage DM $(P=0.630)$, supplement DM ( $P$ $=0.501)$, OM $(P=0.669), \mathrm{CP}(P=0.420)$, aNDFom $(P=0.380)$, EE $(P=0.199)$ and $\mathrm{GE}(P=0.620)$. However, intake and total apparent digestibility of DM, OM, and aNDFom $(P<0.050)$ decreased with oil supplementation, whereas the intake and digestibility of aNDFom were increased $(P<0.010)$ with low-starch supplementation. There were no interactions between starch supplement and oil source supplementation for $\mathrm{pH}$ $(P=0.391), \mathrm{NH}_{3}-\mathrm{N}(P=0.473)$, and total volatile fatty acids $(P=0.441)$. The inclusion of an oil source in supplements decreased $(\mathrm{P}<0.010)$ the acetate concentration in the rumen when compared with supplements without oil, independent of starch level. Supplementation with high-starch increased the numbers of Entodinium $(P<0.010)$, and total protozoa $(P<0.010)$. Furthermore, independently of starch level, the addition of an oil source decreased the population of Dasytricha $(P<0.010)$, Polyplastron $(P<0.010)$, and Diploplastron $(P=$ 0.040). Supplementing animals with low-starch (SH) without oil resulted in a higher proportion of Ruminococcus albus $(P=0.012)$ compared with the other supplements. Moreover, low-starch (SH) supplement, with or without oil, decreased the relative population of Selenomonas ruminantium $(P=0.003)$. The addition of oil in supplements decreased the number of Fibrobacter succinogenes $(P<0.001)$, Ruminococcus flavefasciens $(P<0.001)$, and Archeas $(P<0.001)$, but increased Anaerovibrio lipolytica populations $(P<0.001)$. Oil supplement decreased intake, digestibility, acetate production, protozoan populations, and fibrolytic rumen bacteria. The use of soybean hulls without whole soybean supplementation may be effective in increasing the digestibility of CP and $R$. albus in finishing Nellore steers grazing $B$. brizantha during the dry season.
\end{abstract}

\section{Introduction}

The nutritional strategy to increase uptake of nitrogen by rumen microorganisms in pasture-based systems has focused on improving the energy supply to animals. Dietary energy promotes ammonia incorporation into microbial protein, and thereby increases the amino acid flow to the small intestine (Moorby et al., 2006).

Ammonia is the preferred nitrogen source of fibrolytic bacteria in the rumen, and supply of ruminal degradable fibre (e.g. pectin) may stabilize ruminal $\mathrm{pH}$ and increase ruminal ammonia utilization (Russell et al., 1992). Nevertheless, the rate of absorption of ammonia by ruminants suggests that energy availability, or lack of synchrony between energy and nitrogen supplies, limits the use of available nitrogen by ruminal microorganisms (Huntington, 1997).

Although the inclusion of lipid in diets can be one source of energy, it decreases ruminal organic matter (OM) digestibility and changes the

\footnotetext{
* Correspondence to: Departamento de Zootecnia, Faculdade de Ciências Agrárias e Veterinárias de Jaboticabal, São Paulo State University, Rod. Professor Paulo Donato Castellane, km 5, Rural, Jaboticabal, São Paulo CEP 14884-900, Brazil.

E-mail address: duartejuliana@hotmail.com (J.D. Messana).
} 
site of digestion to the lower parts of the gastrointestinal tract (Plascencia et al., 2003). Consequently, short-chain fatty acid (FA) production in the rumen can be reduced, thereby reducing the risk of metabolic disorders and improving ruminal fermentation parameters (Aschenbach et al., 2011). Moreover, a decrease in the population of protozoa, which predate on ruminal bacteria, may occur when lipids are supplemented, thereby promoting bacterial growth (Kayouli et al., 1986).

Currently, there is a lack of information on starch supplementation combined with whole soybean (oil source) on the rumen microbial populations and fermentation parameters of Nellore steers finishing by grazing tropical grass. The hypothesis of the present study is that when combined with oil, soybean hulls could replace corn as a source of energy and improve fermentation parameters and ruminal microbiota without affecting feed intake. In this study, we accordingly evaluated the effects of starch level [corn (high) or soybean hulls (low)] in supplement with or without whole soybean (oil source) on intake, digestibility, rumen microbial population, and fermentation parameters in Nellore steers grazing Brachiaria brizantha cultivar Xaraés.

\section{Materials and methods}

The protocol used in this experiment was in accordance with the guidelines of the Brazilian College of Animal Experimentation (Colégio Brasileiro de Experimentação Animal) and was approved by the Ethics, Bioethics, and Animal Welfare Committee (Comissão de Ética e Bem Estar Animal) of the São Paulo State University (Unesp), School of Agricultural and Veterinarian Sciences, Jaboticabal, campus (Protocol no. $021119 / 11$ ).

\subsection{Animals and management}

The experiment was conducted at the UNESP (Jaboticabal, SP, Brazil) from May to July 2013, during the dry season. Under the international Köppen classification, the climate is characterized as tropical type Aw with summer rains and a relatively dry winter. The local altitude is $595 \mathrm{~m}$ above sea level, at $21^{\circ} 15^{\prime} 22^{\prime \prime} \mathrm{S}, 48^{\circ} 18^{\prime} 58^{\prime \prime} \mathrm{W}$. The average maximum and minimum annual temperatures are $29.1{ }^{\circ} \mathrm{C}$ and $16.5^{\circ} \mathrm{C}$, respectively, and the average annual precipitation is $105 \mathrm{~mm}$, with $85 \%$ of the rainfall occurring between the months of October and March.

A replicated $4 \times 4$ Latin square experiment, using eight (two steers per treatment) ruminal cannulated Nellore steers $(514 \mathrm{~kg} \pm 30)$ at 24 months of age, was used to evaluate the effects of starch level in supplement, with or without whole soybean (oil source), on intake, nutrient digestibility, ruminal $\mathrm{pH}$, ammonia- $\mathrm{N}\left(\mathrm{NH}_{3}-\mathrm{N}\right)$ and volatile fatty acid (VFA) concentrations, and ruminal microbiology over four 21-d periods. Each period consisted of $14 \mathrm{~d}$ for adaptation to the supplement and $7 \mathrm{~d}$ of sampling.

Initially, the animals were weighed, identified, treated against ectoand endoparasites by administration of ivermectin (Ivomec, Merial, Paulínia, BR), and allocated to four paddocks, each of 0.25 ha. The pasture area was established in 2011, with planting of $B$. brizantha cultivar Xaraés. During the initial study, there was a single application of fertilizer to each paddock, as $\mathrm{N}_{2} \mathrm{P}_{2} \mathrm{O}_{5}: \mathrm{K}_{2} \mathrm{O}(20: 05: 20)$ at a rate of $200 \mathrm{~kg} / \mathrm{ha}$, at the end of the rainy season (May 2013). The paddocks were fitted with smooth wire fencing, waterers (with free access for the animals), and a pair of individual feed bunks.

The experimental treatments were ground corn (high starch) combined with whole soybean; corn without whole soybean; soybean hulls (low starch) combined with whole soybean; and soybean hulls without whole soybean. Crude glycerin was used in all supplements [28\% of dry matter (DM)] as an energy source. Crude glycerin is a byproduct of the biodiesel agroindustry and can be used in ruminant diets without compromising intake or performance (Parsons et al., 2009; Drouillard, 2012). The crude glycerin $[83.90 \%$ glycerol, $1.75 \%$ ether extract (EE),
Table 1

Chemical composition of the ingredients, ingredient proportions and chemical composition of supplements and pasture (\% DM basis).

\begin{tabular}{|c|c|c|c|c|}
\hline Chemical composition & Corn & $\begin{array}{l}\text { Soybean } \\
\text { meal }\end{array}$ & Soybean hulls & $\begin{array}{l}\text { Whole } \\
\text { soybean }\end{array}$ \\
\hline Dry matter & 89.79 & 91.34 & 90.56 & 91.23 \\
\hline Organic matter & 98.76 & 93.69 & 95.71 & 95.11 \\
\hline Crude protein & 9.61 & 50.27 & 15.36 & 41.37 \\
\hline ANDFom & 14.65 & 22.04 & 53.75 & 18.82 \\
\hline Ether extract & 4.94 & 1.71 & 1.60 & 19.80 \\
\hline Gross energy, $\mathrm{MJ} / \mathrm{kg} D M$ & 20.42 & 19.71 & 18.16 & 23.64 \\
\hline \multirow[t]{2}{*}{ Item $^{\mathrm{a}}$} & \multicolumn{2}{|c|}{ High starch } & Low starch & Pasture \\
\hline & Oil & No oil & No oil & \\
\hline
\end{tabular}

\begin{tabular}{|c|c|c|c|c|c|}
\hline \multicolumn{6}{|l|}{ Ingredient proportions } \\
\hline Corn & 18.5 & 31.0 & 0.00 & 0.00 & - \\
\hline Soybean meal & 0.00 & 38.5 & 0.00 & 37.0 & - \\
\hline Soybean hulls & 0.00 & 0.00 & 18.5 & 32.5 & - \\
\hline Whole soybean & 51.0 & 0.00 & 51.0 & 0.00 & - \\
\hline Crude glycerin & 28.0 & 28.0 & 28.0 & 28.0 & - \\
\hline Commercial premix ${ }^{\mathrm{c}}$ & 2.50 & 2.50 & 2.50 & 2.50 & - \\
\hline \multicolumn{6}{|l|}{ Chemical composition } \\
\hline Dry matter & 90.2 & 89.3 & 90.3 & 89.4 & - \\
\hline Organic matter & 92.3 & 92.2 & 91.7 & 91.3 & 92.6 \\
\hline Crude protein & 22.9 & 22.3 & 23.9 & 23.6 & 12.1 \\
\hline ANDFom & 12.7 & 11.1 & 21.9 & 27.1 & 60.4 \\
\hline Starch $^{\mathrm{d}}$ & 17.2 & 24.7 & 4.45 & 3.29 & - \\
\hline Ether extract & 12.4 & 3.62 & 11.8 & 2.58 & 2.16 \\
\hline Gross energy, MJ/kg DM & 21.2 & 19.3 & 20.8 & 18.6 & 18.9 \\
\hline $\begin{array}{l}\text { Metabolizable energy, } \\
\text { MJ/kg } D M^{\mathrm{e}}\end{array}$ & 10.5 & 10.0 & 10.5 & 9.62 & - \\
\hline
\end{tabular}

${ }^{\text {a }}$ High starch = supplement with corn; Low starch = supplement with soybean hulls; Oil $=$ supplement with whole soybean and No Oil $=$ supplement without whole soybean

${ }^{b}$ Average and standard deviation of the mean of samples obtained by technique of simulated grazing in five periods.

c $120 \mathrm{~g}$ Calcium, $30 \mathrm{~g}$ phosphorus, $25 \mathrm{~g}$ sulfur, $80 \mathrm{~g}$ sodium, $330 \mathrm{mg}$ copper, $950 \mathrm{mg}$ manganese, $1220 \mathrm{mg}$ zinc, $24 \mathrm{mg}$ iodine, $20 \mathrm{mg}$ cobalt, $6 \mathrm{mg}$ selenium, and $300 \mathrm{mg}$ fluorine.

${ }^{\mathrm{d}}$ Calculated based on ingredient values from Valadares Filho et al. (2010).

${ }^{\mathrm{e}}$ Metabolizable energy $=$ total apparent digestibility of gross energy $\times 0.82$.

4.30\% ash, and $12.01 \%$ water] used in the present study was acquired from a soybean oil-based biodiesel production company (Cargill, Três Lagoas, Mato Grosso do Sul, Brazil). The proportions of ingredients and chemical compositions of supplements are presented in Table 1.

Animals were provided with experimental supplements at the rate of $1.0 \%$ body weight (BW), daily at 10:00 a.m., in a part of the feed bunks arranged in each paddock, and had ad libitum access to water. The BW of individual steers was recorded at the initiation of each period without a fasting period, to adjust the amount of supplement provided.

Forage mass in each paddock was estimated in each period during the grazing study. The average sward height was estimated by taking readings at 50 sampling points in each paddock, using a stick with $\mathrm{cm}$ graduations (Barthram, 1985). Every $21 \mathrm{~d}$, forage was collected from paddocks at four sites with average sward height to represent the mean forage mass of the paddocks. At these sites, all forage included within the perimeter of a rising plate $\left(0.25 \mathrm{~m}^{2}\right)$ was collected by clipping at $5 \mathrm{~cm}$ above soil level. The clipping samples were dried to a constant weight under forced air at $55^{\circ} \mathrm{C}$. The dry weights of these clippings were multiplied by the paddock area to estimate the forage mass. Paddocks had an average forage mass of $8350.9 \mathrm{~kg} / \mathrm{ha} \pm 865.7$ and an average sward height of $32.0 \mathrm{~cm} \pm 5.7$. The grazing method used was the continuous grazing system (Allen et al., 2011), and the initial average sward height was $39.0 \pm 4.6 \mathrm{~cm}$. Forage samples were collected to be representative of the diets consumed by grazing steers from all pastures in each period during the grazing studies by hand plucking to mimic the forage selected by grazing steers (Johnson, 1978). Hand plucking was performed on the same days as the estimation of dry 
matter intake (DMI) (described later). Samples were dried to a constant weight at $55{ }^{\circ} \mathrm{C}$ under forced air and stored before chemical analysis.

\subsection{Intake estimation}

Intake and nutrient digestibility were estimated in all periods, using the marker method. Lignin isolated, purified, and enriched from Eucalyptus grandis (LIPE ${ }^{\circledR}$; Simões Saliba Research Products, Florestal, Brazil) and indigestible neutral detergent fibre (iNDF) were used to estimate the excretion of faecal matter (as dry weight), and forage intake, respectively. Faecal samples were collected directly from the rectum on days 19,20, and 21 of each period, at 11:00 and 17:00, 09:00 and 15:00, and 07:00 and 13:00 h, during the first, second, and third days of collection, respectively. The faecal samples were dried at $55{ }^{\circ} \mathrm{C}$ for $72 \mathrm{~h}$ and ground in a Wiley mill (Thomas Scientific, Swedesboro, $\mathrm{NJ}$ ) to pass through a 1-mm screen and composited proportionately on each of the $3 \mathrm{~d}$ and at each time of sampling, for each animal, based on faecal dry weights. Approximately $10 \mathrm{~g}$ of each composited faecal sample was sent to the Federal University of Minas Gerais (Belo Horizonte, MG, Brazil) for estimation of the total daily faecal output by LIPE $^{\circledR}$ measurement using an infrared spectroscopy method (Saliba et al., 2013).

The samples of faeces, forage, and concentrate were placed in Ankom bags (Filter bag F57; Ankom Technology Corporation) and incubated in the rumen of a cannulated Nellore animal for a period of $288 \mathrm{~h}$ (Valente et al., 2011). The bags were attached to a $20-\mathrm{cm}$ metal chain when placed in the rumen of each steer. When the bags were withdrawn from the rumen, they were soaked in water for $30 \mathrm{~min}$ and gently washed by hand under running water until the wash water ran clear. The bags were then placed in an Ankom $^{200}$ Fibre Analyzer (Ankom Technology, Fairport, NY, USA), according to the methods described by Van Soest et al. (1991), and the indigestible neutral detergent fibre (iNDF) was determined by weighing the bags with a digital scale after drying in an oven, initially at $55^{\circ} \mathrm{C}$ for $72 \mathrm{~h}$ and then at $105^{\circ} \mathrm{C}$ for $12 \mathrm{~h}$. The residue was considered to be the iNDF. The intake of concentrate was determined from the individual supply of supplement, calculated according to the body weight of the animal. Lignin isolated, purified, and enriched from Eucalyptus grandis was provided for $7 \mathrm{~d}$ by cannula infusion of a 500-mg bolus, with $4 \mathrm{~d}$ to stabilize faecal excretion of the marker, and during the last $3 \mathrm{~d}$ for sample collection (Santos et al., 2011).

Individual forage intakes were estimated by subtracting marker excretion from the concentrate from the total iNDF excretion and dividing the difference by the concentration of the marker in the forage.

\subsection{Proximate analysis}

Diet ingredients, supplements, forage, and faeces were dried at $55{ }^{\circ} \mathrm{C}$ for $72 \mathrm{~h}$, for subsequent chemical analysis. Samples were ground in a Wiley mill (Thomas Scientific, Swedesboro, NJ, USA) to pass through a 1-mm screen, and analysed for DM (method 934.01), OM (method 942.05), and EE (method 920.85) according to the Association of Official Analytical Chemists AOAC (1995). Concentrations of nitrogen were determined by rapid combustion $\left(850^{\circ} \mathrm{C}\right)$, conversion of all nitrogen-combustion products to $\mathrm{N}_{2}$, and subsequent measurement using a thermal conductivity cell $\left(\right.$ Leco $^{\circledast}$ model FP-528; LECO Corporation, St. Joseph, MI). Crude protein was calculated as the percentage of nitrogen in the sample multiplied by 6.25 . The gross energy (GE) content of supplements, forage, and faeces was determined using an adiabatic bomb calorimeter (model 6300; Parr Instrument Company, Moline, IL). Analyses of NDF were conducted using heat-stable $\alpha$ amylase and expressed exclusive of residual ash without the addition of sodium sulphite, according to Van Soest et al. (1991) and adapted for the Ankom ${ }^{200}$ Fibre Analyzer.

\subsection{Ruminal fermentation}

Rumen $\mathrm{pH}, \mathrm{NH}_{3}-\mathrm{N}$, and VFA were measured on day 18 of each period, when rumen fluid samples (approx. $80 \mathrm{~mL}$ ) were collected by hand through a cannulated rumen at $0,3,6,12$, and $18 \mathrm{~h}$ after supplementation (10:00 a.m.). Rumen fluid was obtained from several sites within the rumen and was subsequently strained through two layers of cheesecloth. Immediately after collection, the $\mathrm{pH}$ of the rumen fluid was determined using a digital potentiometer (ORION 710A, Boston, $\mathrm{MA})$. An aliquot of the collected fluid $(50 \mathrm{~mL})$ was poured into a plastic bottle and frozen at $-20{ }^{\circ} \mathrm{C}$ for subsequent analysis of $\mathrm{NH}_{3}-\mathrm{N}$ concentration. Ruminal fluid $\mathrm{NH}_{3}-\mathrm{N}$ was analysed by distilling with $2 \mathrm{M}$ $\mathrm{KOH}$ in a micro-Kjeldahl system, according to the original procedures of Fenner (1965). The samples collected for analysis of VFA were centrifuged at $13.000 \times g\left(4{ }^{\circ} \mathrm{C}\right)$ for $30 \mathrm{~min}$ and quantified by gas chromatography (GC Shimatzu model 20-10, automatic injection) using a capillary column (SP-2560, $100 \mathrm{~m} \times 0.25 \mathrm{~mm}$ in diameter and $0.02 \mathrm{~mm}$ in thickness, Supelco, Bellefonte, PA) according to the methodology of Palmquist and Conrad (1971).

\subsection{Rumen microbial profile}

Ruminal microbial (bacteria, archea, and protozoa) samples were collected on day 18 , after $3 \mathrm{~h}$ of supplementation $(1000 \mathrm{~h})$. For protozoa, population cell counts were determined from aliquots of rumen content, by taking handfuls of rumen contents from the midpoint of the rumen, which were preserved in formalin (a solution of equal parts water and $370 \mathrm{~mL} / \mathrm{L}$ formaldehyde) according to D'Agosto and Carneiro (1999). Ciliate protozoan species were identified and quantified in a chamber of a Sedgewick-Rafter cell, according to Dehority (1984). Each sample was homogenized and $1 \mathrm{~mL}$ of ruminal content was pipetted and transferred to vials containing Lugol's solution, according to the modified methodology of D' Agosto and Carneiro (1999). After $15 \mathrm{~min}$, $9 \mathrm{~mL}$ of $30 \%$ glycerin was added to the vials. To quantify the protozoa, $1 \mathrm{~mL}$ of the contents of each vial was pipetted to fill the chamber of the Sedgewick-Rafter cell. The ciliates were counted according to Dehority (1984).

For the quantification and identification of rumen bacteria, $50 \mathrm{~g}$ of the ruminal contents was obtained by taking a handful of rumen contents from the midpoint of the rumen and placing it in a container. A second handful of rumen contents was squeezed to obtain the liquid, which was added to the same container (Henderson et al., 2013). The samples were weighed and then $50 \mathrm{~mL}$ of phosphate saline buffer $(\mathrm{pH}$ 7.4) was immediately added, followed by vigorous stirring for $3 \mathrm{~min}$, and subsequent filtration with a mesh fabric $(100 \mu \mathrm{m})$. The filtrate was subjected to centrifugation at $16,000 \times g$ for $10 \mathrm{~min}$ at $4{ }^{\circ} \mathrm{C}$. The supernatant was discarded and the remaining precipitate was resuspended in $4 \mathrm{~mL}$ of Tris-EDTA buffer $(10 \times, \mathrm{pH} 8.0)$. The resuspended contents were centrifuged at $16,000 \times g$ for $10 \mathrm{~min}$ at $4{ }^{\circ} \mathrm{C}$, the supernatant was discarded, and the precipitate was immediately stored at $-20{ }^{\circ} \mathrm{C}$ for 2 months. DNA extraction (pellet) was conducted in $250 \mathrm{mg}$ of sample using a FastDNA ${ }^{\circ}$ SPIN Kit for Soil (MP Biomedical, LLC). The integrity and quantity of the DNA was checked by electrophoresis on agarose gel $(0.8 \%)$, and complementary DNA was assessed by spectrophotometry (Thermo Scientific NanoDrop ${ }^{\mathrm{TM}}$ 1000) for evaluation of its quality and quantity. We used qPCR for quantification of total bacteria and relative quantification of cellulolytic bacteria [Fibrobacter succinogenes, Ruminococcus albus, Ruminococcus flavefasciens, Anaerovibrio lipolytica, Selenomonas ruminantium, and Methanogens (Archeas)]. The primers used in this study are shown in Table 2.

Three concentrations $(400,600$, and $800 \mathrm{nM})$ of forward and reverse primers were tested to determine the minimum primer concentration giving the lowest threshold cycle and to reduce non-specific amplification before starting the reaction.

The amplifications were performed in triplicate and negative controls (containing no DNA template) were run in the assay. The reactions 
Table 2

PCR primers used in this study for the quantification of specific rumen microbes by qPCR.

\begin{tabular}{|c|c|c|c|}
\hline Primer & Sequence $\left(5^{\prime}\right.$ to $\left.3^{\prime}\right)$ & Product size (bp) & Efficiency (\%) \\
\hline \multirow[t]{2}{*}{ Total bacteria ${ }^{\mathrm{a}, \mathrm{b}}$} & F: CGGCAACGACAACCC & 130 & 99 \\
\hline & R: CCATTGTAGCACCTGTGTAGCC & & \\
\hline \multirow[t]{2}{*}{ Fibrobacter succinogenes $^{\mathrm{b}}$} & F: GGTATGGGATGAGCTTGC & 121 & 98 \\
\hline & R: GCCTGCCCCTGAACTATC & & \\
\hline \multirow[t]{2}{*}{ Ruminococcus flavefasciens ${ }^{\mathrm{b}}$} & F: GGACGATAATGACGGTACTT & 132 & 96 \\
\hline & R: GCAATC(CT)GAACTGGGACAAT & & \\
\hline \multirow[t]{2}{*}{ Ruminococcus albus ${ }^{\mathrm{b}}$} & F: CCCTAAAAGCAGTCTTAGTTCG & 175 & 96 \\
\hline & R: CCTCCTTGCGGTTAGAACA & & \\
\hline \multirow[t]{2}{*}{ Total Archeas ${ }^{\mathrm{c}}$} & F: TTC GGT GGA TCD CAR AGR GC & 140 & 95 \\
\hline & R:GBA RGT CGW AWC CGT AGA ATC C & & \\
\hline \multirow[t]{2}{*}{ Anaerovibrio lipolytica $^{\mathrm{e}}$} & F:TGGGTGTTAGAAATGGATTCTAGTG & 82 & 98 \\
\hline & R: TCGAAATGT TGTCCCCAT CTG & & \\
\hline \multirow[t]{2}{*}{ Selenomonas ruminantium ${ }^{\mathrm{d}}$} & F: GGCGGGAAGGCAAGTCAGTC & 83 & 98 \\
\hline & R: CTCTCCTGCACTCAAGAAAGACAG & & \\
\hline
\end{tabular}

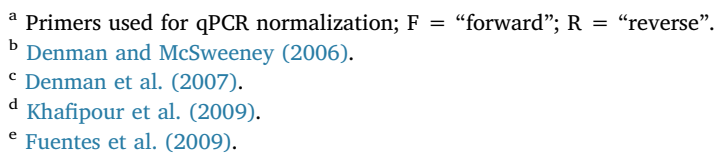

were conducted using a 7500 Real Time PCR System (Applied Biosystems, Foster City, California 94404, USA). Rox was used as a passive reference dye. The qPCR reaction was carried out using $100 \mathrm{ng}$ of total DNA in a reaction mixture containing the following reagents: $7.5 \mu \mathrm{L}$ of $\mathrm{SYBR}^{\circledast}{ }^{\oplus}$ Green PCR Master Mix (Bio-Rad, Hercules, California, USA), 10 pmol of each primer, and $\mathrm{H}_{2} \mathrm{O}$ to a final volume of $12.5 \mu \mathrm{L}$. Cycling conditions were $50{ }^{\circ} \mathrm{C}$ for $2 \mathrm{~min}$; $95^{\circ} \mathrm{C}$ for $10 \mathrm{~min}$; and 40 cycles with denaturation at $95^{\circ} \mathrm{C}$ for $15 \mathrm{~s}$, annealing at $60^{\circ} \mathrm{C}$ for $1 \mathrm{~min}$, and extension at $78{ }^{\circ} \mathrm{C}$ for $30 \mathrm{~s}$. After the amplification cycles, a final step was added in which the temperature was increased from 60 to $95^{\circ} \mathrm{C}$ to obtain a dissociation curve of the reaction products, which was used for analysing the specificity of amplification.

Relative quantification was used to determine species proportions. The results were expressed as a $16 \mathrm{~S}$ rDNA ratio of general bacteria, using the following equation:

Relative quantification $=2^{-(\mathrm{Ct} \text { target}-\mathrm{Ct} \text { total bacteria })}$

where $\mathrm{C}_{\mathrm{t}}$ is defined as the number of cycles required for the fluorescent signal to cross the threshold.

\subsection{Microbial protein yield}

To determine the microbial protein yield, spot samples of urine were collected on day 21 of each experimental period. The urine samples were collected from each steer $4 \mathrm{~h}$ after feeding (supplement), as described by Barbosa et al. (2006). The samples were collected in 50-mL polypropylene containers during voluntary urination. The samples were filtered through two layers of cheesecloth and 10-mL aliquots were diluted in $40 \mathrm{~mL}$ of $0.036 \mathrm{~N}$ sulphuric acid to prevent bacterial degradation of purine derivatives and uric acid precipitation (Valadares et al., 1997), and subsequently used for the quantification of urinary levels of urea nitrogen, creatinine, and allantoin.

Allantoin in the diluted urine was analysed using the colorimetric method as described by Chen and Gomes (1992). The final point colorimetric method was used to determine uric acid concentrations in urine (Labtest Diagnostic S.A., Lagoa Santa, Brazil). The total excretion of purine derivatives was calculated from the sum of the quantities of allantoin and uric acid excreted in the urine, expressed as mmol/d.

Absorbed purines (X, mmol/d) were estimated from the excretion of purine derivatives $(\mathrm{Y}, \mathrm{mmol} / \mathrm{d})$ using the following equation:

$Y=0.85 \mathrm{X}+0.385 \mathrm{BW}^{0.75}$,

where 0.85 is the recovery of absorbed purine as purine derivatives, and $0.385 \mathrm{BW}^{0.75}$ is the endogenous contribution to purine excretion
(Verbic et al., 1990).

The ruminal synthesis of nitrogenous compounds (Pabs, mmol/d) was calculated based on the amount of absorbed purines (X, mmol/d) according to the equation proposed by Chen and Gomes (1992):

$\mathrm{Nmic}(\mathrm{g} /$ day $)=(70 \times \mathrm{Pabs}) /(0.83 \times 0.134 \times 1.000)$,

where 70 is the $\mathrm{N}$ content in purines $(\mathrm{mg} / \mathrm{mol}$ of $\mathrm{N})$; 0.134 is the average Npurines: $\mathrm{N}$-total ratio in the bacteria that were isolated from the rumen; and 0.83 is the intestinal digestibility of microbial purines. The microbial efficiency was calculated as total microbial biomass per total digestible nutrient (TDN) intake (Valadares Filho et al., 2010).

Total urinary volume was estimated using the ratio of creatinine excretion per unit of BW to its concentration in the urine (Chizzotti et al., 2006). Urinary creatinine excretion (UCE) is related to the shrunk body weight (SBW), and estimated according to the equation proposed by Costa and Silva et al. (2012):

$\mathrm{UCE}(\mathrm{g} /$ day $)=00.0345 \times \mathrm{SBW}^{0.9491}$

Daily excretion of nitrogen in the urine and faeces was calculated as the product of nitrogen concentration and the urinary volume and faeces production after $24 \mathrm{~h}$. Samples of faeces and urine were evaluated for nitrogen content using a LECO FP-528 nitrogen analyzer (LECO Corp., St. Joseph, MI). The amount of nitrogen absorbed was obtained from the difference between the nitrogen ingested and the nitrogen excreted in the faeces, whereas the nitrogen balance $(\mathrm{N}$ retained, g/day) was calculated as follows:

$\mathrm{N}$ retained $(\mathrm{g})=\mathrm{N}$ consumed $(\mathrm{g})-\mathrm{N}$ faeces $(\mathrm{g})-\mathrm{N}$ urine $(\mathrm{g})$

where $\mathrm{N}$ retained $=$ nitrogen retained in the organism; $\mathrm{N}$ consumed $=$ nitrogen consumed by the animal; $\mathrm{N}$ faeces = nitrogen excreted in the faeces; and $\mathrm{N}$ urine $=$ nitrogen excreted in the urine.

\subsection{Statistical analysis}

The experimental design was a replicated $4 \times 4$ Latin square with a $2 \times 2$ factorial arrangement of treatments [high (corn) or low (soybean hulls) starch, with or without a source of oil (whole soybean)]. Data on intake and apparent digestibility were analysed considering a replicated Latin square design using the MIXED procedures (SAS, version 9.2, Inst. Inc., Cary, NC, USA, 2009). The model included the fixed effect of treatment and Latin square, and random effects of period, animal, and error.

Repeated measurements ANOVA was conducted using the mixed model procedure of SAS (SAS, version 9.2, Inst. Inc., Cary, NC) for a 
factorial analysis of time and treatment effects on data of $\mathrm{pH}, \mathrm{NH}_{3}-\mathrm{N}$, and VFA. The model included the fixed effect of treatment, time, and treatment $\times$ time interaction, and random effects of period, animal, and error.

Data on protozoa were transformed to $\log ^{10}$, plus a drive to meet the requirements of the SAS analysis. The analysis considered a replicated Latin square design using the MIXED procedures (SAS, version 9.2). The model included the fixed effect of treatment and Latin square, and random effects of period, animal, and error. Statistical analyses for bacterial populations were performed using the MIXED procedures. The model included the fixed effect of treatment, and random effects of period, animal, and error.

Homogeneity of the data was verified using the UNIVARIATE procedure of SAS. Studentized residuals were plotted against the predicted values using the plot procedure to analyse data for outliers. The LSMEANS command of the mixed procedure of SAS was used to calculate mean values. When the treatments were significant, the means were compared with Fisher's tests using the PDIFF option in the LSMEANS command. The level of significance used to assess differences among means was $\alpha=0.05$.

\section{Results}

There were no interactions between starch level and oil source (whole soybean) in supplements on intake of DM (\% of BW, $P=0.602$; $\mathrm{kg} / \mathrm{d}, P=0.703)$, forage DM $(P=0.630)$, total supplement DM $(P=$ $0.501)$, OM $(P=0.669), \mathrm{CP}(P=0.420)$, aNDFom $(P=0.380)$, EE $(P$ $=0.199)$, and GE $(P=0.620)$. However, there was an effect of starch level supplements alone on intake of aNDFom $(P<0.010)$ and $\mathrm{EE}$ $(P<0.010)$. The addition of an oil source decreased the intake of DM $(P<0.010)$, forage DM $(P=0.010)$, OM $(P=0.010)$, and NDF $(P<0.010)$ independently of starch supplements (Table 3$)$.

No interactions were observed between starch level in supplements and oil supplementation on digestibility of DM $(P=0.269)$, OM $(P=$ $0.161)$, aNDFom $(P=0.321)$, EE $(P=0.130)$, and GE $(P=0.273)$. However, there was an interaction between starch and oil supplementation on CP digestibility $(P=0.010)$. Thus, animals supplemented with low-starch (soybean hulls) and without oil (no whole soybean) showed greater $(10.77 \%)$ digestibility of CP than those supplemented with high-starch (corn) and without oil. The digestibility of DM $(P<0.010)$, OM $(P<0.010)$, aNDFom $(P=0.031)$, and GE $(P=$
0.022) decreased with oil source supplementation, but digestibility of EE $(P<0.010)$ increased with the inclusion of an oil source, independent of starch (corn or soybean hulls) supplements (Table 3).

There were no interactions between starch and oil source supplements for $\mathrm{pH}(P=0.391), \mathrm{NH}_{3}-\mathrm{N}(P=0.473)$, total VFA $(P=0.441)$, acetate $(P=0.950)$, propionate $(P=0.881)$, butyrate $(P=0.922)$, isobutyrate $(P=0.421)$, valerate $(P=0.790)$, isovalerate $(P=0.859)$, and A:P ratio $(P=0.080$, Table 4$)$. Nevertheless, the inclusion of an oil source in the supplement decreased $(9.25 \%, P<0.010)$ the acetate concentration when compared with supplementation without oil, independent of starch level. Furthermore, there was an effect of time on $\mathrm{pH}, \mathrm{NH}_{3}-\mathrm{N}$, and VFA concentrations of Nellore steers grazed on pasture during the finishing phase $(\mathrm{P}<0.010)$.

In relation to numbers of protozoa, there were no interactions between starch level in supplements and oil source supplementation on populations of Entodinium $(P=0.750)$, Dasytricha $(P=0.942)$, Isotricha $(P=0.693)$, Polyplastron $(P=0.221)$, Diploplastron $(P=$ $0.592)$, and total protozoa $(P=0.801)$. However, animals fed with high-starch (corn) supplements showed greater Entodinium populations $(3.79 \%, P<0.010)$ and total protozoa $(3.26 \%, P<0.010)$ than those supplemented with low-starch (soybean hulls). Furthermore, the addition of oil in the supplements, independently of starch level supplement used, decreased the population of Dasytricha $(P<0.010)$, Polyplastron $(P<0.010)$, and Diploplastron $(P=0.043$; Table 5$)$.

A significant interaction between starch level and oil source supplements was observed for Ruminococcus albus $(P=0.0120)$. Supplementing the animals with low-starch (soybean hulls) without oil (whole soybean) increased the relative proportion of $R$. albus compared with the other supplements. In addition, there was also interaction between starch level and oil source supplements for $S$. ruminantium ( $P$ $=0.003$ ), where, low-starch (soybean hulls) supplement, with or without oil, decreased the rumen population of $S$. ruminantium of Nellore steers. Moreover, the addition of whole soybean in supplements decreased the number of $F$. succinogenes $(P<0.001)$, R. flavefasciens $(P<0.001)$, and Archeas $(P<0.001)$, but increased the number of $A$. lipolytica $(P<0.001)$, independently of starch supplements. In contrast, supplementation with high-starch (corn) decreased the population of Archeas when compared with supplementation with low-starch $(P<0.001$; Table 6).

The production of rumen microbial $\mathrm{N}$ and microbial protein yield, estimated from the urinary excretion of purine derivatives, did not

Table 3

Effect of supplements containing high or low starch with or without whole soybean (Oil or No Oil) on intake and digestibility of Nellore steers on pasture during finishing phase.

\begin{tabular}{|c|c|c|c|c|c|c|c|c|}
\hline \multirow[t]{2}{*}{ Item } & \multicolumn{2}{|c|}{ High starch ${ }^{\mathrm{a}}$} & \multicolumn{2}{|c|}{ Low starch ${ }^{b}$} & \multirow[t]{2}{*}{ SEM } & \multirow[b]{2}{*}{ Starch } & \multicolumn{2}{|l|}{ P-value } \\
\hline & Oil & No oil & Oil & No oil & & & Oil & Starch $\times$ Oil \\
\hline \multicolumn{9}{|c|}{ Intake, \% of BW } \\
\hline $\mathrm{DM}$ & 2.37 & 2.50 & 2.39 & 2.47 & 0.12 & 0.840 & 0.042 & 0.602 \\
\hline \multicolumn{9}{|l|}{ Intake, $\mathrm{kg} / \mathrm{d}$} \\
\hline $\mathrm{DM}$ & 12.2 & 13.0 & 12.1 & 12.7 & 0.59 & 0.541 & $<0.010$ & 0.703 \\
\hline Forage DM & 7.04 & 7.81 & 7.02 & 7.55 & 0.85 & 0.572 & 0.010 & 0.630 \\
\hline Suppl. DM & 5.12 & 5.17 & 5.09 & 5.18 & 0.05 & 0.763 & 0.051 & 0.501 \\
\hline OM & 11.2 & 12.0 & 11.2 & 11.7 & 0.65 & 0.450 & 0.010 & 0.669 \\
\hline $\mathrm{CP}$ & 2.08 & 2.20 & 2.18 & 2.23 & 0.23 & 0.150 & 0.051 & 0.420 \\
\hline aNDFom & 4.89 & 5.24 & 5.31 & 5.91 & 0.28 & $<0.010$ & $<0.010$ & 0.380 \\
\hline $\mathrm{EE}$ & 0.78 & 0.35 & 0.76 & 0.29 & 0.02 & $<0.010$ & $<0.010$ & 0.199 \\
\hline GE, MJ/d & 243 & 248 & 239 & 241 & 12.1 & 0.240 & 0.491 & 0.620 \\
\hline \multicolumn{9}{|c|}{ Digestibility, g/kg DM } \\
\hline $\mathrm{DM}$ & 623 & 656 & 619 & 665 & 1.99 & 0.730 & $<0.010$ & 0.269 \\
\hline $\mathrm{OM}$ & 648 & 679 & 641 & 690 & 1.88 & 0.712 & $<0.010$ & 0.161 \\
\hline $\mathrm{CP}$ & $577^{\mathrm{bc}}$ & $559^{c}$ & $592^{\mathrm{b}}$ & $627^{\mathrm{a}}$ & 4.80 & $<0.010$ & 0.400 & 0.010 \\
\hline aNDFom & 519 & 535 & 542 & 583 & 2.99 & $<0.010$ & 0.031 & 0.321 \\
\hline $\mathrm{EE}$ & 708 & 545 & 687 & 611 & 2.72 & 0.430 & $<0.010$ & 0.130 \\
\hline GE & 603 & 632 & 612 & 623 & 2.13 & 0.971 & 0.022 & 0.273 \\
\hline
\end{tabular}

Means within a row with different superscripts differ $(P<0.050)$.

${ }^{\text {a }}$ High starch (supplement with corn): range from 172 to $247 \mathrm{~g} / \mathrm{kg}$ of starch in DM supplement.

${ }^{\mathrm{b}}$ Low starch (supplement with soybean hulls): range from 32.9 to $44.5 \mathrm{~g} / \mathrm{kg}$ of starch in DM supplement. 
Table 4

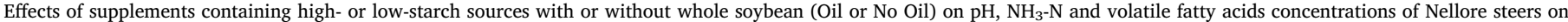
pasture during finishing phase.

\begin{tabular}{|c|c|c|c|c|c|c|c|c|c|c|c|}
\hline \multirow[t]{2}{*}{ Item } & \multicolumn{2}{|c|}{ High starch ${ }^{\mathrm{a}}$} & \multicolumn{2}{|c|}{ Low starch $^{\mathrm{b}}$} & \multirow[t]{2}{*}{ SEM } & \multicolumn{6}{|l|}{ P-value } \\
\hline & Oil & No oil & Oil & No oil & & Starch & Oil & Starch $\times$ Oil & Time & Starch $\times$ Time & Oil $\times$ Time \\
\hline $\mathrm{pH}$ & 6.48 & 6.49 & 6.43 & 6.49 & 0.05 & 0.53 & 0.44 & 0.391 & $<0.010$ & 0.020 & 0.710 \\
\hline $\begin{array}{l}\mathrm{NH}_{3}-\mathrm{N}, \mathrm{mg} / \mathrm{dL} \\
V F A, \mathrm{mM}\end{array}$ & 19.5 & 20.3 & 20.7 & 20.2 & 1.37 & 0.64 & 0.86 & 0.473 & 0.160 & 0.359 & 0.730 \\
\hline Total VFA & 84.2 & 89.3 & 87.5 & 89.0 & 5.73 & 0.58 & 0.24 & 0.441 & $<0.010$ & $<0.010$ & 0.541 \\
\hline Acetate & 41.5 & 45.8 & 43.6 & 48.0 & 1.85 & 0.19 & $<0.01$ & 0.950 & $<0.010$ & $<0.010$ & 0.060 \\
\hline Propionate & 20.6 & 21.9 & 21.8 & 23.0 & 2.06 & 0.57 & 0.55 & 0.881 & $<0.010$ & 0.039 & 0.923 \\
\hline Butyrate & 17.6 & 15.7 & 15.9 & 13.8 & 1.40 & 0.17 & 0.12 & 0.922 & $<0.010$ & 0.131 & 0.070 \\
\hline Isobutyrate & 1.10 & 1.22 & 1.09 & 1.12 & 0.09 & 0.45 & 0.32 & 0.421 & $<0.010$ & 0.499 & 0.412 \\
\hline Valerate & 1.95 & 1.95 & 1.88 & 1.90 & 0.13 & 0.57 & 0.94 & 0.790 & $<0.010$ & 0.181 & 0.731 \\
\hline Isovalerate & 1.75 & 1.91 & 1.65 & 1.79 & 0.15 & 0.24 & 0.11 & 0.859 & $<0.010$ & 0.393 & 0.090 \\
\hline A:P ratio ${ }^{c}$ & 2.29 & 2.49 & 2.43 & 2.45 & 0.09 & 0.35 & 0.10 & 0.080 & $<0.010$ & 0.231 & 0.130 \\
\hline
\end{tabular}

Means within a row with different superscripts differ $(\mathrm{P}<0.050)$.

${ }^{\text {a }}$ High starch (supplement with corn): range from 172 to $247 \mathrm{~g} / \mathrm{kg}$ of starch in DM supplement.

${ }^{\mathrm{b}}$ Low starch (supplement with soybean hulls): range from 32.9 to $44.5 \mathrm{~g} / \mathrm{kg}$ of starch in DM supplement.

${ }^{c}$ Acetate to propionate ratio.

differ among treatments $(\mathrm{g} / \mathrm{d}: P=0.852$ and $\mathrm{g} / \mathrm{kg}$ TDN: $P=0.801)$. Additionally, there were no interactions between starch level and oil supplementation on crude protein intake relative to digestible OM intake (g CP/kg DOMI; $P=0.529$; Table 7).

\section{Discussion}

The reduction of intake in animals fed with oil supplements may be due to a depressive effect on rumen microbial populations and ruminal digestion or to a low palatability of lipids in the whole grain (Patra and Yu, 2013). It was the case in the present study, since the animals supplemented with oil reduced the intake of DM (5.59\%), OM (5.48\%), and aNDFom $(8.52 \%)$ independently of starch supplement. In addition, there was a reduction in the digestibility of DM (6.01\%) and aNDFom $(5.12 \%)$ when compared with supplements without an oil source.

The reduction in intake when feed was supplemented with an oil source (whole soybean) may be due to a decline in three main fibrolytic bacteria assessed in this study (F. succinogenes, $R$. flavefasciens, and $R$. albus), as well as certain fibrolytic protozoa, such as those in the genus Polyplastron, which may result in an increase rumen retention time due to reduced fibre digestion and particle outflow rates (Demeyer, 1987).

Additionally, another factor that can affect nutrient digestibility with lipid supplementation is the type of basal diet (type and quantity of lipids). Thus, for grazing animals, forage content, and the association between forage and supplement are important factors to be considered (Nörnberg et al., 2004). In this sense, the effect of adding an oil source to whole soybean in the diet $(2.48 \%$ to $6.34 \% \mathrm{EE})$ was confirmed in terms of the reduction of intake forage DM (8.46\%) of animals grazing tropical pasture. The dietary addition of oil at levels greater than 2-3\% of DM may decrease the digestibility of fibrous feedstuffs such as soybean hulls and forage DM, by inhibiting fibrolytic bacteria (Palmquist, 1988). Shain et al. (1993) reported that the rate of digestion of aNDFom was lower for a combination of soybean hulls (low-starch) with oil than for soybean hulls alone when provided in a forage-based diet. However, the energy provided by an oil source may compensate for the potential reduction in energy derived from fermentation of soybean hull fibre. Consequently, the intake of digestible energy may be unaffected, or even improved, with higher amounts of dietary oil (Ludden et al., 1995).

In contrast, animals supplemented with low-starch (soybean hulls) showed a greater $(9.80 \%)$ intake of aNDFom than those supplemented with high-starch (corn). This may be explained by the greater aNDFom digestibility $(6.36 \%)$ in low-starch diets than in high-starch diets. Soybean hulls are high in aNDFom and ADFom, but are low in lignin (2\% lignin; NRC, 1996), resulting in an in vitro DM digestibility that may exceed 90\% (Ludden et al., 1995). In addition, soybean hulls have a small feed particle size and high specific gravity (Mertens, 1997) resulting in a more rapid ruminal scape and reduction of ruminal fill (Iraira et al., 2013).

Moreover, when starch supplementation was combined with oil, there was a modification in ruminal protein metabolism. The rate of degradation of soybean hulls (e.g. pectin; Ludden et al., 1995) may explain the increase in the digestibility of $\mathrm{CP}$ in supplements with lowstarch and without oil. The carbohydrate composition (pectin) of soybean hulls results in a better synchronization between protein and energy supplies, increasing the efficiency of microbial protein yield in the

Table 5

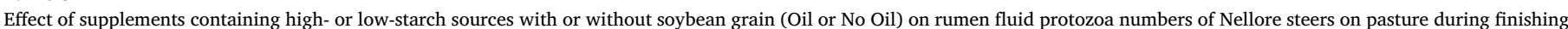
phase.

\begin{tabular}{|c|c|c|c|c|c|c|c|c|}
\hline \multirow[t]{2}{*}{ Protozoa $\left(\mathrm{n} \times 10^{4} \mathrm{~mL}^{-1}\right)^{\mathrm{c}}$} & \multicolumn{2}{|c|}{ High starch ${ }^{\mathrm{a}}$} & \multicolumn{2}{|c|}{ Low starch ${ }^{\mathrm{b}}$} & \multirow[t]{2}{*}{ SEM } & \multirow[b]{2}{*}{ Starch } & \multicolumn{2}{|l|}{ P-value } \\
\hline & Oil & No oil & Oil & No oil & & & Oil & Starch $\times$ Oil \\
\hline Entodinium & 5.75 & 5.83 & 5.55 & 5.60 & 0.07 & $<0.010$ & 0.281 & 0.750 \\
\hline Dasytricha & 4.13 & 4.48 & 4.32 & 4.66 & 0.11 & 0.104 & $<0.010$ & 0.942 \\
\hline Isotricha & 3.41 & 3.64 & 3.53 & 3.64 & 0.15 & 0.661 & 0.240 & 0.693 \\
\hline Polyplastron & 3.63 & 3.89 & 3.48 & 4.01 & 0.14 & 0.882 & $<0.010$ & 0.221 \\
\hline Diploplastron & 3.64 & 3.95 & 3.60 & 4.12 & 0.19 & 0.713 & 0.043 & 0.592 \\
\hline Total protozoa & 5.77 & 5.88 & 5.59 & 5.67 & 0.06 & $<0.010$ & 0.113 & 0.801 \\
\hline
\end{tabular}

Means within a row with different superscripts differ $(P<0.050)$.

${ }^{a}$ High starch (supplement with corn): range from 172 to $247 \mathrm{~g} / \mathrm{kg}$ of starch in DM supplement.

${ }^{\mathrm{b}}$ Low starch (supplement with soybean hulls): range from 32.9 to $44.5 \mathrm{~g} / \mathrm{kg}$ of starch in DM supplement.

${ }^{\mathrm{c}} \log ^{10}$ of number of protozoa. 
Table 6

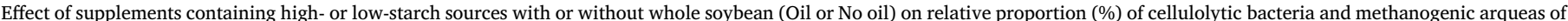
Nellore steers on pasture during finishing phase.

\begin{tabular}{|c|c|c|c|c|c|c|c|c|}
\hline \multirow[t]{2}{*}{ Item } & \multicolumn{2}{|c|}{ High starch ${ }^{1}$} & \multicolumn{2}{|c|}{ Low $\operatorname{starch}^{2}$} & \multirow[t]{2}{*}{ SEM } & \multicolumn{3}{|l|}{$P$-value } \\
\hline & Oil & No oil & Oil & No oil & & Starch & Oil & Starch $\times$ Oil \\
\hline Fibrobacter succinogenes & 0.078 & 0.107 & 0.070 & 0.103 & 0.0034 & 0.108 & $<0.001$ & 0.522 \\
\hline Ruminococcus albus & $0.003^{\mathrm{c}}$ & $0.009^{\mathrm{b}}$ & $0.003^{\mathrm{c}}$ & $0.010^{\mathrm{a}}$ & 0.0001 & 0.002 & $<0.001$ & 0.012 \\
\hline Ruminococcus flavefaciens & 0.003 & 0.021 & 0.003 & 0.021 & 0.0003 & 0.212 & $<0.001$ & 0.746 \\
\hline Anaerovibrio lipolytica & 0.019 & 0.002 & 0.021 & 0.002 & 0.0004 & 0.242 & $<0.001$ & 0.111 \\
\hline Selenomonas ruminantium & $0.069^{b}$ & $0.079^{\mathrm{a}}$ & $0.030^{\mathrm{c}}$ & $0.030^{\mathrm{c}}$ & 0.0007 & $<0.001$ & 0.003 & 0.003 \\
\hline Archeas & 0.714 & 0.876 & 0.818 & 1.004 & 0.0065 & $<0.001$ & $<0.001$ & 0.124 \\
\hline
\end{tabular}

Means within a row with different superscripts differ $(P<0.050)$.

${ }^{1} \mathrm{High}$ starch (supplement with corn): range from 172 to $247 \mathrm{~g} / \mathrm{kg}$ of starch in DM supplement.

${ }^{2}$ Low starch (supplement with soybean hulls): range from 32.9 to $44.5 \mathrm{~g} / \mathrm{kg}$ of starch in DM supplement.

Table 7

Effect of supplements containing high- or low-starch sources with or without whole soybean (Oil or No oil) on urinary excretion of total purines, absorbed microbial purine, and ruminal microbial protein yield of Nellore steers on pasture during finishing phase.

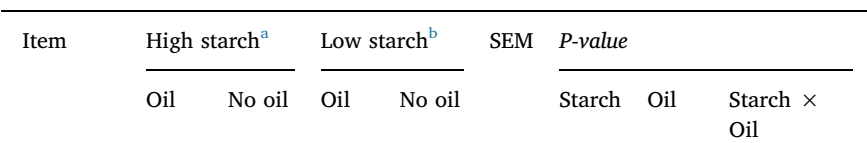

\begin{tabular}{|c|c|c|c|c|c|c|c|c|}
\hline \multicolumn{9}{|l|}{ Microbial N, } \\
\hline $\mathrm{g} / \mathrm{d}$ & 278 & 251 & 257 & 247 & 49.7 & 0.791 & 0.730 & 0.862 \\
\hline $\mathrm{g} / \mathrm{kg}$ TDN & 37.2 & 31.3 & 34.6 & 31.7 & 6.28 & 0.861 & 0.483 & 0.801 \\
\hline \multicolumn{9}{|c|}{ Microbial protein yield, } \\
\hline $\mathrm{g} / \mathrm{d}$ & 1740 & 1569 & 1604 & 1545 & 311 & 0.801 & 0.710 & 0.852 \\
\hline g/kg TDN & 233 & 196 & 216 & 198 & 39.3 & 0.862 & 0.480 & 0.801 \\
\hline \multicolumn{9}{|c|}{$C P$ intake per $D O M I^{c}$} \\
\hline $\mathrm{g} / \mathrm{kg}$ & 268 & 286 & 292 & 294 & 25.4 & 0.441 & 0.452 & 0.529 \\
\hline
\end{tabular}

Means within a row with different superscripts differ $(P<0.050)$.

${ }^{a}$ High starch (supplement with corn): range from 172 to $247 \mathrm{~g} / \mathrm{kg}$ of starch in DM supplement.

${ }^{b}$ Low starch (supplement with soybean hulls): range from 32.9 to $44.5 \mathrm{~g} / \mathrm{kg}$ of starch in DM supplement.

${ }^{c}$ DOMI: Digestible organic matter intake.

rumen of animals on grazing pasture (Russell et al., 1992).

However, our results showed that the production of rumen microbial $\mathrm{N}$ and microbial protein yield, estimated from the urinary excretion of purine derivatives, did not differ among all supplement combinations. These findings in relation to microbial protein yield are in accordance with those reported by Henning et al. (1993), who showed that synchronization between energy and $\mathrm{N}$ availability may be of less importance to bacterial growth efficiency than the energy supply pattern. This may be explained by the fact that recycling of $\mathrm{N}$ by the animal can be used to synchronize the ruminal supply of these nutrients. Thus, the recycling of $\mathrm{N}$ to the rumen and subsequent incorporation of recycled $\mathrm{N}$ into microbial protein may well be central to the success of lower N content diets in animal production (Calsamiglia et al., 2010).

In this study, the mean crude protein intake relative to digestible OM intake was $285.22 \mathrm{~g}$ of $\mathrm{CP} / \mathrm{kg}$ of DOMI. Poppi and McLennan (1995) stated that losses of dietary protein, as ammonia absorbed from the rumen and excreted as urea in urine, will occur when the CP content of forage exceeds $210 \mathrm{~g} / \mathrm{kg}$ digestible OM.

Since the fermentability of diet is dependent on the extent and rate of OM digestibility, the use of feedstuffs high in sugars, starch, and potentially digestible aNDFom (e.g. pectin) in the diet of ruminants can increase the concentration of fermentable OM (Allen, 1997). Highly fermentable feeds result in a rapid production of VFA that reduce ruminal $\mathrm{pH}$ when the rate of production exceeds the buffering capacity and absorption (Aschenbach et al., 2011). However, the current results showed that whole soybean supplementation reduced OM digestibility, but there was no effect of starch, oil, or interactions between starch and oil supplements on rumen $\mathrm{pH}$. This may be due to the fact that the starch-based supplements used in our experiment increased the number of Entodinium and total protozoa. The presence of a high population of protozoa, particularly Entodioniomorphs, may contribute to stabilizing ruminal $\mathrm{pH}$ and slowing the ruminal fermentation of carbohydrates (Kurihara et al., 1978). Because protozoa readily engulf ruminal bacteria and starch granules, they may reduce the formation of bacterial slime in the rumen and modulate acid production (Dehority, 1998).

Regarding protozoan populations, animals fed an oil source (whole soybean) in supplements had decreased numbers of Dasytricha $(7.55 \%)$, Polyplastron (10.00\%), and Diploplastron (10.28\%) in the rumen in relation to the other treatments. Several studies have shown that dietary lipids reduce protozoa concentrations in the rumen (Newbold and Chamberlain, 1988; Firkins et al., 2007). The toxicity of high dietary oil concentrations to rumen protozoa is due to their limited ability to absorb and transform lipids, resulting in swelling and consequent rupture of the protozoan cells (Williams, 1989).

In addition, studies with faunated and defaunated ruminants have shown that when protozoa are present, protein digestion is increased compared with digestion by bacteria alone, particularly if the dietary protein is of low degradability (Kayouli et al., 1986). In this sense, our results are in agreement with these studies, in which the reduction in protozoan populations also caused a reduction of apparent $\mathrm{N}$ digested in animals fed with oil supplementation.

In our study, ruminal $\mathrm{NH}_{3}-\mathrm{N}$ concentrations ranged between 19.46 and $20.71 \mathrm{mg} / \mathrm{dL}$. These concentrations were above the threshold (15 mg/dL) suggested by Detmann et al. (2009) for maximizing productive efficiency for cattle fed low-quality tropical forage.

Oil source supplementation reduced acetate concentration $(9.25 \%)$ in the rumen fluid of animals. This may indicate the inhibitory activity of oil on ruminal cellulolytic bacteria, resulting in an incomplete digestion of aNDFom (Doreau and Ferlay, 1995). Moreover, concentrations of total VFA, acetate, propionate, butyrate, and valerate increased immediately after feeding, which would typically be expected in animals supplemented on grazing pasture, because manipulation of the diet by increasing the proportion of concentrate is a strategy to optimize ruminal fermentation by increasing the amount of digestible OM, and consequently providing more substrate for the rumen microbial population (Doreau et al., 2011).

Additionally, in the present study, we found a high proportion of $R$. albus in the rumen of steers fed with low-starch without oil, which may be due to the growth or the activity of fibrolytic bacteria that have been positively favoured by this diet, because the low-starch (soybean hulls) diets had more fibrous material than the high-starch (corn) diets.

High-starch diets lead to a decreased efficiency of fibre digestion, associated with a decreased number of certain fibrolytic bacteria, i.e. $R$. flavefasciens (Tajima et al., 2001), F. succinogenes (Tajima et al., 2001; Brown et al., 2006; Fernando et al., 2010), and Butyrivibrio fibrisolvens (Fernando et al., 2010), and a shift towards more lactate producers such as lactobacilli (Brown et al., 2006). Moreover, there was also an interactive effect between starch and oil (whole soybean) supplements on 
the proportion of $S$. ruminantium, where, low-starch supplements combined with oil supplements decreased the rumen population of $S$. ruminantium of Nellore steers. This may be due the fact that Selenomonas utilize starch for growth (Tajima et al., 2001). Consequently, if this bacterium has more substrate available, the diets with high-starch increases (SFC) its numbers compared to the other diets.

\section{Conclusion}

High (corn)- or low (soybean hulls)-starch supplements with or without oil (whole soybean) have a similar feeding value when used for animals grazing pasture, as indicated by the similar diet intake and digestibility, rumen fermentation parameters, and protozoa populations of cattle fed these supplements. Whole soybean supplementation decreases intake, digestibility, acetate production, protozoa population, and fibrolytic rumen bacteria. The use of soybean hulls without oil supplementation may be effective for increasing the digestibility of $\mathrm{CP}$ and the rumen population of $R$. albus in finishing Nellore steers grazing $B$. brizantha cultivar Xaraés during the dry season.

\section{Conflict of interest}

The authors declare that this paper has no conflict of interest.

\section{Acknowledgments}

We thank the São Paulo Research Foundation (FAPESP, Brazil) Grant nos. 2012/08284-5, 2011/00060-8 and 2014/09033-1 for supported this research, and Cargill for providing feed supplies for experimental supplements.

\section{References}

Allen, M.S., 1997. Relationship between fermentation acid production in the rumen and the requirement for physically effective fiber. J. Dairy Sci. 80, 1447-1462.

Allen, V.G., Batello, C., Berretta, E.J., Hodgson, J., Kothmann, M., Li, X., McIvor, J., Milne, J., Morris, C., Peeters, A., Sanderson, M., 2011. An international terminology for grazing lands and grazing animals. Grass Forage Sci. 66, 2-28.

Aschenbach, J.R., Penner, G.B., Stumpff, F., Gäbel, G., 2011. Ruminant nutrition symposium: role of fermentation acid absorption in the regulation of ruminal $\mathrm{pH}$. J. Anim. Sci. 89, 1092-1107.

Association of Official Analytical Chemists (AOAC), 1995. Official methods of analysis. 16th ed. Assoc. Off. Anal. Chem., Arlington, VA.

Barbosa, A.M., Valadares, R.F.D., Valadares Filho, S.C., Véras, R.M.L., Leão, M.I. Detmann, E., Paulino, M.F., Marcondes, M.I., Souza, M.A., 2006. Efeito do período de coleta de urina, dos níveis de concentrado e de fontes protéicas sobre a excreção de creatinina, de uréia e de derivados de purina e a produção microbiana em bovinos Nelore. Rev. Bras. Zootec. 35, 870-877.

Barthram G.T., 1985. Experimental techniques: The HFRO sward stick. In: The hill Farming Research Organization Biennial Report 1984/1985. Hill Farming Research Organization, Penicuik, UK. pp. 29-30.

Brown, M.S., Ponce, C.H., Pulikanti, R., 2006. Adaptation of beef cattle to high-concentrate diets: performance and ruminal metabolism. J. Anim. Sci. 84, 25-33.

Calsamiglia, S., Ferret, A., Reynolds, C.K., Kristensen, N.B., Van Vuuren, A.M., 2010. Strategies for optimizing nitrogen use by ruminants. Animal 4, 1184-1196.

Chen, X.B., Gomes, M.J., 1992. Estimation of Microbial Protein Supply to Sheep and Cattle Based on Urinary Excretion of Purine Derivatives: an Overview of Technical Details. International Feed Research Unit, Occasional Publ. (Rowett Research Institute: Aberdeen, UK).

Chizzotti, M.L., Valadares Filho, S.C., Valadares, R.F.D., Chizzotti, F.H.M., Campos, J.M.S., Marcondes, M.I., Fonseca, M.A., 2006. Intake, digestibility and urinary excretion of urea and purine derivatives in heifers with different body weights. R. Bras. Zootec. 35, 1813-1821.

Costa and Silva, L.F., Valadares Filho, S.D.C., Chizzotti, M.L., Rotta, P.P., Prados, L.F., Valadares, R.F.D., Zanetti, D., Braga, J.M.D.S., 2012. Creatinine excretion and relationship with body weight of Nellore cattle. Rev. Bras. Zoot. 41, 807-810.

D'Agosto, M., Carneiro, M.E., 1999. Evaluation of lugol solution used for counting rumen ciliates. Rev. Bras. Zool. 16, 725-729.

Dehority, B.A., 1984. Evaluation of subsampling and fixation procedures used for counting rumen protozoa. Appl. Environ. Microbiol. 48, 182-185.

Dehority, B.A., 1998. Generation times of Epidinium caudatum and Entodinium caudatum, determined in vitro by transferring at various time intervals. J. Anim. Sci. 76, 1189-1196.

Demeyer, D.I., 1987. Interdependence des effects de la defaunation sur l'activite muralttique, le volume et la cinetique du contenu de rumen. Result. Prelim. Hypotheses
Reprod. Nutr. Dev. 27, 161-162.

Denman, S.E., McSweeney, C.S., 2006. Development of a real-time PCR assay for monitoring anaerobic fungal and cellulolytic bacterial populations within the rumen. FEMS Microbiol. Ecol. 58, 572-582.

Denman, S.E., Tomkins, N.W., Mcsweeney, C.S., 2007. Quantitation and diversity analysis of ruminal methanogenic populations in response to the antimethanogenic compound bromochloromethane. FEMS Microbiol. Ecol. 62, 313-322.

Detmann, E., Paulino, M.F., Mantovani, H.C., Valadares Filho, S.D.C., Sampaio, C.B., Souza, M.A., Lazzarini, I., Detmann, K.S., 2009. Parameterization of ruminal fibre degradation in low-quality tropical forage using Michaelis-Menten kinetics. Livest. Sci. 126 (1), 136-146.

Doreau, M., Ferlay, A., 1995. Effect of dietary lipids on nitrogen metabolism in the rumen: a review. Livest. Prod. Sci. 43, 97-110.

Doreau, M., Martin, C., Eugène, M., Popova, M., Morgavi, D.P., 2011. Leviers d'action pour réduire la production de méthane entérique par les ruminants. In: M. Doreau, R. Baumont, and J. M. Perez, editors, Gaz à effet de serre en élevage bovin: Le méthane. (In French.) INRA Prod. Anim. 24, pp. 461-474.

Drouillard, J.S., 2012. Utilization of crude glycerin in beef cattle. In: Makkar, H.P.S. (Ed.), Biofuel Co-products as Livestock Feed - Opportunities and Challenges. Food and agriculture organization of the United Nation, Rome, Italy, pp. 155-161.

Fenner, H., 1965. Method for determining total volatile bases in rumen fluid by steam distillation. J. Dairy Sci. 48, 249-251.

Fernando, S.C., Purvis, H.T., Najar, F.Z., Sukharnikov, L.O., Krehbiel, C.R., Nagaraja, T.G., Roe, R.A., Desilva, U., 2010. Rumen microbial population dynamics during adaptation to a high grain diet. Appl. Environ. Microbiol. 76, 7482-7490.

Firkins, J.L., Yu, Z., Morrison, M., 2007. Ruminal nitrogen metabolism: perspectives for integration of microbiology and nutrition for dairy. J. Dairy Sci. 90, E1-E16.

Fuentes, M.C., Calsamiglia, S., Cardozo, P.W., Vlaeminc, B., 2009. Effect of pH and level of concentrate in the diet on the production of biohydrogenation intermediates in a dual-flow continuous culture. J. Dairy Sci. 92, 4456-4466.

Henderson, G., Cox, F., Kittelmann, S., Miri, V.H., Zethof, M., Noel, S.J., Waghorn, G.C., Janssen, P.H., 2013. Effect of DNA extraction methods and sampling techniques on the apparent structure of cow and sheep rumen microbial communities. PLoS One 8 (9), e74787. http://dx.doi.org/10.1371/journal.pone.0074787.

Henning, P.H., Steyn, D.,G., Meissner, H.H., 1993. Effect of synchronization of energy and nitrogen supply on ruminal characteristics and microbial growth. J. Anim. Sci. 71, 2516-2528.

Huntington, G.B., 1997. Starch utilization by ruminants: from basics to the bunk. J. Anim. Sci. $75,852-867$.

Iraira, S.P., Ruíz de la Torre, J.L., Rodríguez-Prado, M., Calsamiglia, S., Manteca, X., Ferret, A., 2013. Feed intake, ruminal fermentation, and animal behavior of beef heifers fed forage free diets containing nonforage fiber sources. J. Anim. Sci. 91, 3827-3835.

Johnson, A.D., 1978. Sample preparation and chemical analysis of vegetation. In: Manejte, L.T. (Ed.), Measurement of Grassland Vegetation and Animal Production. Commonweath Agricultural Bureax, Aberustwysth, UK, pp. 96-102.

Kayouli, C., Van Nevel, C.J., Dendooven, R., Demeyer, D.I., 1986. Effect of defaunation and refaunation of the rumen on rumen fermentation and $\mathrm{N}$-flow in the duodenum of sheep. Arch. Anim. Nutr. 36, 827-837.

Khafipour, E., Li, S., Plaizier, J.C., Krause, D.O., 2009. Rumen microbiome composition determined using two nutritional models of subacute ruminal acidosis. Appl. Environ. Microbiol. 75, 7115-7124.

Kurihara, Y., Takechi, T., Shibata, F., 1978. Relationship between bacteria and ciliate protozoa in the rumen of a sheep fed a purified diet. J. Agric. Sci. 90, 373-382.

Ludden, P.A., Cecava, M.J., Hendrix, K.S., 1995. The value of soybean hulls as a replacement for corn in beef cattle diets formulated with or without added fat. J. Anim. Sci. 73, 2706-2711.

Mertens, D.R., 1997. Creating a system for meeting the fiber requirements of dairy cows. J. Dairy Sci. 80, 1463-1481.

Moorby, J.M., Dewhurst, R.J., Evans, R.T., Danelon, J.L., 2006. Effects of dairy cow diet forage proportion on duodenal nutrient supply and urinary purine derivative excretion. J. Dairy Sci. 89, 3552-3562.

National Research Council - NRC, 1996. Nutrient Requirements of Beef Cattle, 6 ed. Nat Acad. Sci., Washington, D.C. 242p.

Newbold, C.J., Chamberlain, D.G., 1988. Lipids as rumen defaunating agents. Proc. Nutr. Soc. $47,154$.

Nörnberg, J.L., Stumpf Júnior, W., López, J., Costa, P.B., 2004. Valor do farelo de arroz integral como fonte de gordura na dieta de vacas Jersey na fase inicial de lactação: digestibilidade aparente de nutrientes. Br. J. Anim. Sci. 33, 2412-2421.

Palmquist, D.L., 1988. The feeding value of fats. In: Orskov, E.R. (Ed.), Feed Science. Elsevier Science, New York, pp. 293.

Palmquist, D.L., Conrad, H.R., 1971. Origin of plasma fatty acids in lactating cows fed high grain or high fat diets. J. Dairy Sci. 54, 1025-1033.

Parsons, G.L., Shelor, M.K., Drouillard, J.S., 2009. Performance and carcass traits of finishing heifers fed crude glycerin. J. Anim. Sci. 87, 653-657.

Patra, A.K., Yu, Z., 2013. Effects of coconut and fish oils on methane production, fermentation, abundance and diversity of rumen microbial populations in vitro. J. Dairy Sci. $96,1782-1792$.

Plascencia, A., Mendoza, G.D., Vásquez, C., Zinn, R.A., 2003. Relationship between body weight and level of fat supplementation on fatty acid digestion in feedlot cattle. J. Anim. Sci. 81, 2653-2659.

Poppi, D.P., McLennan, S.R., 1995. Protein and energy utilization by ruminants at pasture. J. Anim. Sci. 73, 278-290.

Russell, J.B., O'Connor, J.D., Fox, D.G., Van Soest, P.J., Sniffen, C.J., 1992. A net carbohydrate and protein system for evaluating cattle diets: I. Ruminal fermentation. J. Anim. Sci. 70, 3551-3561. 
Santos, S.A., Valadares Filho, S.C., Detmann, E., Valadares, R.F.D., Ruas, J.R.M., Amaral, P.M., 2011. Different forage sources for F1 Holstein $\times$ Gir dairy cows. Livest. Sci. 142, 48-58.

Saliba, E.O.S., Gonçalves, N.C., Barbosa, G.S.S.C., Borges, A.L.C.C., Rodriguez, N.M., Moreira, G.R., Silva, F.A., 2013. Evaluation of the infrared spectroscopy method for the quantification of nanolipe marker in feces of dairy cattle. In: Oltjen, J.W., Kebreab, E., Lapierre, H. (Eds.), Energy and Protein Metabolism and Nutrition in Sustainable Animal Production. CA, USA, pp. 247-248.

Shain, D.H., Sindt, M.H., Grant, R.J., Klopfenstein, T.J., Stock, R.A., 1993. Effect of a soybean hull: soy 1ecithin: soapstock mixture on ruminal digestion and performance of growing beef calves and lactating dairy cattle. J. Anim. Sci. 71, 1266.

Tajima, K., Aminov, R.I., Nagamine, T., Matsui, H., Nakamura, M., Benno, Y., 2001. Dietdependent shifts in the bacterial population of the rumen revealed with real-time PCR. Appl. Environ. Microbiol. 67, 2766-2774.

Valadares Filho, S.C., Machado, P.A.S., Chizzotti, M.L., Amaral, H.F., Magalhães, C.A., Rocha Jr., V.R., Capelle, E.R., 2010. CQBAL 3.0. Brazilian Tables of the Chemical Composition of Feeds for Ruminants. 〈http://cqbal.agropecuaria.ws/webcqbal/en/

\section{index.php> (Accessed 10 October 2015).}

Valadares, R.F.D., Gonçalves, L.C., Rodriguez, N.M., 1997. Níveis de proteína em dietas de bovinos. 4. Concentrações de amônia ruminal e uréia plasmática e excreções de uréia e creatinina. Rev. Bras. Zoot. 26, 1270-1278.

Valente, T.N.P., Detmann, E., Queiroz, A.C., Valadares Filho, S.C., Gomes, D.I., Figueiras, J.F., 2011. Evaluation of ruminal degradation profiles of forages using bags made from different textiles. R. Bras. Zootec. 40, 2565-2573.

Van Soest, P.J., Robertson, J.B., Lew, B.A., 1991. Methods for dietary fiber, neutral detergent fiber, and nonstarch polysaccharides in relation to animal nutrition. J. Dairy Sci. 74, 3583-3597.

Verbic, J., Chen, X.B., MacLeod, N.A., Ørskov, E.R., 1990. Excretion of purine derivatives by ruminants. Effect of microbial nucleic acid infusion on purine derivative excretion by steers. J. Agric. Sci. 114, 243-248.

Williams, A.G., 1989. Metabolic activities of rumen protozoa. In: Nolan, J.V., Leng, R.A., Demeyer, D.I. (Eds.), The Roles of Protozoa and Fungi in Ruminant Digestion. Penambul Books, Armidale, Australia, pp. 97-126. 